\title{
The Influence of Current Ratio and Debt to Asset Ratio on Return on Assets at PT Selaras Aditama
}

\author{
Ilham \\ Sekolah Tinggi Ilmu Ekonomi YPN Karawang \\ E-mail: ilham.balanipa@gmail.com
}

\begin{abstract}
This study aims to determine the effect of current ratio and debt to asset ratio on return on assets at PT Seelaras Aditama. The method used was explanatory research with a sample of 85 respondents. The analysis technique uses statistical analysis with regression testing, correlation, determination and hypothesis testing. The results of this study current ratio have a significant effect on return on assets by $7.3 \%$, the hypothesis test obtained a significance of $0,000<0.05$. Debt to asset ratio has a significant effect on return on assets of $55.1 \%$, the hypothesis test obtained a significance of $0,000<0.05$. Current ratio and debt to asset ratio simultaneously have a significant effect on return on assets by $96.7 \%$, hypothesis testing obtained significance of $0,000<0.05$.
\end{abstract}

Keywords: Current ratio; debt to asset ratio; return on asset

\section{INTRODUCTION}

In the era of globalization, competition in the business world is increasingly competitive (Ismail, Sulur, Akib, \& Salam, 2016; Jamaluddin, Sari, Akib, Kasmita, \& Tadampali, 2019; Niswaty, AM, Saleh, Baharuddin, \& Arhas, 2019; Samsir, 2017). This has an impact on companies in Indonesia. Both companies in services, trade, and manufacturing. This has been proven by the many new businesses that are always popping up from small companies to large companies. And this will cause the level of competition between companies to become increasingly stringent. And every company must have the same goal which is to get the maximum profit or profit.

This advantage is also used by companies to maintain their business. To find out the success of a company's profits, a financial statement is needed (Hanum, 2017; Harahap, 2009). Financial statements are obtained to provide information about a company's finances (Annisya, Lindrianasari, \& Asmaranti, 2016; Kasmir, 2014b; Munawir, 2010). The information contained in the financial statements will assist various parties in formulating or considering financial decision making. Financial statements as a benchmark of the success of management in operating the company for one year period (Hery, 2019, 2015; Horne, J.C. dan Wachowicz, 2007).

This financial statement analysis can assess the company's financial performance. The company's financial performance is needed to see the prospects or potential for the company's development in the future, especially in profitability (Bockholt, Hemdrup Kristensen, Colli, Meulengracht Jensen, \& Vejrum Wæhrens, 2020; Chen, 2010; Tzouvanas, Kizys, Chatziantoniou, \& Sagitova, 2019). Profitability is the company's ability to make a profit in 


\author{
230|Jurnal Administrare: Jurnal Pemikiran Ilmiah dan Pendidikan Administrasi Perkantoran \\ Volume 6 Number 2 July- December 2019. Pages 229-236
}

relation to sales, total assets, and own capital (Bouzgarrou, Jouida, \& Louhichi, 2018; Pessarossi, Thevenon, \& Weill, 2020; Sutrisno, 2013). The profitability of a company can be measured through Return On Assets (ROA). Return On Assets (ROA) is a measure of the effectiveness of management in managing its investments. In addition, the return on investment shows the productivity of all company funds, both loan capital, and own capital. The lower (smaller) the ratio is the less good, and vice versa. This means that this ratio is used to measure the effectiveness of the company's overall operations.

In addition to a company's profitability, liquidity ratios and solvency ratios are also important to measure (Rahma, A.M., Cipta, W., \& Yudiaatmaja, 2016; Susianti, 2018; Susilawati, 2012). The liquidity ratio shows how the company can fulfill its obligations and finance all of its operations. The commonly used liquidity ratio is the Current Ratio (CR). Current Ratio (CR) is the most common measure used to determine the ability to meet shortterm obligations because the ratio shows how far the demands of short-term creditors are met by assets that are estimated to be cash in the same period as the debt maturity (Brigham \& Houston, 2011).

From the measurement results of the current Ratio, if the ratio is low, it can be said that the company is less capital to pay its obligations. However, if the ratio measurement results are high, it is not certain that the company's condition is good. This can happen because cash is not used as well as possible. To say the condition of a company is good in its current ratio, the comparison of current assets with its current liabilities must be in accordance with the standard ratio used.

In running its business, the company is involved with the name of debt. Debt is an obligation that must be paid by a company to another party within a certain period due to transactions that have occurred in the past. The amount of corporate debt is closely related to solvency. While the solvency ratio is a comparison between the amount of assets owned by the company with debts that must be borne.

Debt to Asset Ratio is a debt ratio that is used to measure the ratio between total debt to total assets. In other words, how much the company's assets are financed by debt or how much the company's debt affects the management of assets (Kasmir, 2014a).

\title{
METHOD
}

The type of research used is associative, where the aim is to find out the relationship between variables. The population in this study financial statements for 5 years PT. Seelaras Aditama. The sampling technique in this study is saturated sampling, where all members of the population are sampled. Thus the sample in this study was financial statements for 5 years. In analyzing the data used the instrument test, classical assumption test, regression, coefficient of determination and hypothesis testing. 


\section{RESULT AND DISCUSSION}

Current Ratio (CR) and Debt to Asset Ratio (DAR) are factors that can affect Return on Assets (ROA) on company profits, especially in this study, PT. Seelaras Aditama.

\section{Descriptive Analysis}

In this test used to determine the minimum and maximum scores, mean scores and standard deviations of each variable. The results are as follows:

\section{Table 1.}

\section{Descriptive Statistics Analysis Results}

Descriptive Statistics

\begin{tabular}{lr|r|r|r|r}
\hline & N & \multicolumn{1}{|c}{ Minimum } & Maximum & \multicolumn{1}{c}{ Mean } & \multicolumn{1}{c}{ Std. Deviation } \\
\hline CR & 5 & 47.0 & 86.4 & 63.754 & 17.0973 \\
\hline DAR & 5 & 61.4 & 78.1 & 67.820 & 8.4780 \\
\hline ROA & 5 & 1.0 & 2.6 & 1.642 & .5817 \\
\hline Valid N (listwise) & 5 & & & & \\
\hline
\end{tabular}

The current ratio obtained a minimum value of $47 \%$ and a maximum value of $86.4 \%$ with an average of $63.754 \%$ with a standard deviation of $17.0973 \%$. Debt to asset ratio obtained a minimum value of $61.4 \%$ and a maximum value of $78.1 \%$ with a mean score of $67.820 \%$ with a standard deviation of $8.4780 \%$. Return on assets obtained a minimum variance of $1.0 \%$ and a maximum value of $2.6 \%$ with an average of $1.642 \%$ with a standard deviation of $0.581 \%$.

\section{Multiple Linear Regression Analysis}

This regression test is intended to determine changes in the dependent variable if the independent variable changes. The test results are as follows:

Table 2.

Results of Multiple Linear Regression Testing

\begin{tabular}{|c|c|c|c|c|c|c|}
\hline \multicolumn{7}{|c|}{ Coefficients $^{\mathrm{a}}$} \\
\hline & & \multicolumn{2}{|c|}{ Unstandardized Coefficients } & \multirow{2}{*}{$\begin{array}{c}\text { Standardized } \\
\text { Coefficients } \\
\text { Beta }\end{array}$} & \multirow[b]{2}{*}{$\mathrm{t}$} & \multirow[b]{2}{*}{ Sig. } \\
\hline & & B & Std. Error & & & \\
\hline \multirow[t]{3}{*}{1} & (Constant) & 5.954 & .623 & & 9.563 & .011 \\
\hline & $\mathrm{CR}$ & .030 & .006 & .878 & 5.049 & .037 \\
\hline & DAR & .092 & .012 & 1.336 & 7.687 & .017 \\
\hline
\end{tabular}

a. Dependent Variable: ROA

Based on the test results in the above table, the regression equation $\mathrm{Y}=5.954+0.030 \mathrm{X} 1+$ $0.092 \mathrm{X} 2$ is obtained. A constant of 5.954 means that if there is no current ratio and debt to asset ratio, then there is a return on asset value of 5.954 points. Current ratio coefficient of 0.030 , this number is positive, meaning that every time there is an increase in the current ratio of 0.030 , the 
232 Jurnal Administrare: Jurnal Pemikiran Ilmiah dan Pendidikan Administrasi Perkantoran

Volume 6 Number 2 July- December 2019. Pages 229-236

return on assets will also increase by 0.030 points. Debt to asset ratio regression coefficient of 0.092 , this number is positive meaning that every time there is an increase in debt to asset ratio of 0.092 then the return on assets will also increase by 0.092 points.

\section{Correlation Coefficient Analysis}

Correlation coefficient analysis is intended to determine the degree of relationship strength of the independent variables on the dependent variable either partially or simultaneously. The test results are as follows:

Table 3.

Results of Current Ratio Correlation Coefficient Testing Against Return on Assets

\begin{tabular}{llrrr}
\multicolumn{5}{c}{ Correlations $^{\text {a }}$} \\
\hline \multicolumn{1}{c}{ CR } & ROA \\
\hline CR & Pearson Correlation & 1 & .027 \\
\cline { 2 - 4 } & Sig. (2-tailed) & -.027 & .966 \\
\hline ROA & Pearson Correlation & .966 & 1 \\
\cline { 2 - 4 } & Sig. (2-tailed) & & \\
\hline
\end{tabular}

a. Listwise $\mathrm{N}=5$

Based on the test results obtained by a correlation value of 0.027 means that the current ratio has a very weak relationship to return on assets.

Table 4.

Test Results Correlation Coefficient Debt to Asset Ratio Against Return on Assets.

Correlations $^{\mathrm{a}}$

\begin{tabular}{llr|r}
\hline & & DAR & ROA \\
\hline DAR & Pearson Correlation & 1 & .742 \\
\cline { 2 - 4 } & Sig. (2-tailed) & & .151 \\
\hline \multirow{2}{*}{ ROA } & Pearson Correlation & -.742 & 1 \\
\cline { 2 - 4 } & Sig. (2-tailed) & .151 & \\
\hline
\end{tabular}

a. Listwise $\mathrm{N}=5$

Based on the test results obtained a correlation value of 0.742 means that debt to asset ratio has a strong relationship with return on assets.

Table 5.

Test Results Correlation Coefficient Current Ratio and Debt to Asset Ratio Simultaneously Against Return on Assets.

Model Summary

\begin{tabular}{|c|c|c|c|c|}
\hline & & Voder summs & ary & \\
\hline Model & $\mathrm{R}$ & R Square & Adjusted R Square & $\begin{array}{l}\text { Std. Error of the } \\
\text { Estimate }\end{array}$ \\
\hline 1 & $.984^{\mathrm{a}}$ & .967 & .935 & .1488 \\
\hline
\end{tabular}

a. Predictors: (Constant), DAR, CR 
Based on the test results obtained by the correlation value of 0.984 means that the current ratio and debt to asset ratio simultaneously have a very strong relationship to return on assets.

\section{Analysis of the Coefficient of Determination}

Analysis of the coefficient of determination is intended to determine the percentage of influence of the independent variable on the dependent variable either partially or simultaneously. The test results are as follows:

Table 6.

Results of Current Ratio Determination Coefficient Tests on Return on Assets

\begin{tabular}{|c|c|c|c|c|}
\hline \multicolumn{5}{|c|}{ Model Summary } \\
\hline Model & $\mathrm{R}$ & R Square & $\begin{array}{l}\text { Adjusted R } \\
\text { Square }\end{array}$ & $\begin{array}{l}\text { Std. Error of the } \\
\text { Estimate }\end{array}$ \\
\hline 1 & $.027^{\mathrm{a}}$ & .073 & .723 & 3.679 \\
\hline
\end{tabular}

a. Predictors: (Constant), Current Ratio (X1)

Based on the test results obtained a determination value of 0.073 means that the current ratio has an influence contribution of $7.3 \%$ on return on assets.

Table 7.

Test Results Determination Coefficient Debt to Asset Ratio Against Return on Assets Model Summary

\begin{tabular}{|c|c|c|c|c|}
\hline Model & $\mathrm{R}$ & R Square & $\begin{array}{l}\text { Adjusted R } \\
\text { Square }\end{array}$ & $\begin{array}{l}\text { Std. Error of the } \\
\text { Estimate }\end{array}$ \\
\hline 1 & $.742^{\mathrm{a}}$ & .551 & .478 & 3.576 \\
\hline
\end{tabular}

a. Predictors: (Constant), Debt to Asset Ratio (X2)

Based on the test results obtained a determination value of 0.551 means that debt to asset ratio has an influence contribution of $55.1 \%$ to return on assets.

Table 8.

Test Results Determination Coefficient Current Ratio and Debt to Asset Ratio Against Return on Assets

\begin{tabular}{l|lr|rrr}
\hline \multicolumn{6}{c}{ Model Summary } \\
\hline Model & \multicolumn{2}{c}{} & \multicolumn{1}{c}{$\begin{array}{c}\text { Adjusted R } \\
\text { Square }\end{array}$} & $\begin{array}{c}\text { Std. Error of the } \\
\text { Estimate }\end{array}$ \\
\hline 1 & & R Square & .967 & .935 & .1488 \\
\hline
\end{tabular}

a. Predictors: (Constant), DAR, CR

Based on the test results obtained a determination value of 0.967 means that the current ratio and debt to asset ratio simultaneously have an influence contribution of $96.7 \%$ to return on assets, while the remaining $3.3 \%$ is influenced by other factors. 
234|Jurnal Administrare: Jurnal Pemikiran Ilmiah dan Pendidikan Administrasi Perkantoran Volume 6 Number 2 July- December 2019. Pages 229-236

\section{Hypothesis Testing}

Hypothesis testing with a t-test is used to find out which partial hypotheses are accepted.

Table 9.

Current Ratio Hypothesis Test Results Against Return on Assets.

Coefficients $^{\text {a }}$

\begin{tabular}{|c|c|c|c|c|c|c|}
\hline \multirow{2}{*}{\multicolumn{2}{|c|}{ Model }} & \multicolumn{2}{|c|}{$\begin{array}{l}\text { Unstandardized } \\
\text { Coefficients }\end{array}$} & \multirow{2}{*}{$\begin{array}{c}\text { Standardized } \\
\text { Coefficients } \\
\text { Beta }\end{array}$} & \multirow[b]{2}{*}{$\mathrm{t}$} & \multirow[b]{2}{*}{ Sig. } \\
\hline & & $\mathrm{B}$ & Std. Error & & & \\
\hline \multirow[t]{2}{*}{1} & (Constant) & 3.700 & 1.287 & & 4.321 & .000 \\
\hline & CR & .134 & .020 & .027 & 4.047 & .000 \\
\hline
\end{tabular}

a. Dependent Variable: ROA

Based on the test results in the above table, the value of $t_{\text {count }}>t_{\text {table }}$ or (4.047> 3.182) is obtained, thus the first hypothesis proposed that there is a significant influence between the current ratio on return on assets is accepted.

Table 10.

Debt to Asset Ratio Hypothesis Test Results Against Return on Assets

\begin{tabular}{|c|c|c|c|c|c|c|}
\hline \multicolumn{7}{|c|}{ Coefficients $^{\mathrm{a}}$} \\
\hline & & \multicolumn{2}{|c|}{ Unstandardized Coefficients } & $\begin{array}{l}\text { Standardized } \\
\text { Coefficients }\end{array}$ & & \\
\hline \multicolumn{2}{|c|}{ Model } & $\mathrm{B}$ & Std. Error & Beta & $\mathrm{t}$ & Sig. \\
\hline \multirow[t]{2}{*}{1} & (Constant) & 5.093 & 1.813 & & 2.809 & .000 \\
\hline & DAR & .551 & .027 & .742 & 4.916 & .000 \\
\hline
\end{tabular}

a. Dependent Variable: ROA

Based on the test results in the above table, the value of $t_{\text {count }}>t_{\text {table }}$ or $(4.918>3.182)$ is obtained, thus the second hypothesis proposed that there is a significant influence between debt to asset ratio on return on assets is accepted.

Hypothesis testing with the F test is used to find out which simultaneous hypotheses are accepted.

Table 11.

Hypothesis Test Results Current Ratio and Debt to Asset Ratio Against Return on Assets.

\begin{tabular}{|c|c|c|c|c|c|c|}
\hline \multicolumn{7}{|c|}{ ANOVA $^{\mathbf{a}}$} \\
\hline & & Sum of Squares & df & Mean Square & $\mathrm{F}$ & Sig. \\
\hline \multirow[t]{3}{*}{1} & Regression & 1.309 & 2 & .655 & 29.565 & $.033^{\mathrm{b}}$ \\
\hline & Residual & .044 & 2 & .022 & & \\
\hline & Total & 1.353 & 4 & & & \\
\hline
\end{tabular}

a. Dependent Variable: ROA

b. Predictors: (Constant), DAR, CR 
Based on the test results in the above table, the calculated $F_{\text {count }}>F_{\text {table }}$ or $(29.565>9.280)$, thus the third hypothesis proposed that there is a significant influence between the current ratio and Debt to Asset Ratio on Return on Assets is accepted.

\section{CONCLUSION}

Based on the results of the study found that, Current Ratio significant effect on Return on Assets with an influence contribution of $7.3 \%$. Hypothesis testing obtained $t_{\text {count }}>t_{\text {table }}$ or (4.047> 3.182). Debt to Asset Ratio has a significant effect on Return on Assets with a contribution of $55.1 \%$. Hypothesis testing obtained $t_{\text {count }}>t_{\text {table }}$ or $(4.918>3.182)$. Current Ratio and Debt to Asset Ratio have a significant effect on Return on Assets with a contribution of 96.7\% while the remaining 3.3\% is influenced by other factors. Hypothesis testing obtained by calculating the $\mathrm{F}_{\text {count }}>\mathrm{F}_{\text {table }}$ or $(29.565>9.280$

\section{REFERENCES}

Annisya, M., Lindrianasari, \& Asmaranti, Y. (2016). Pendeteksian Kecurangan Laporan Keuangan Menggunakan Fraud Diamond. Jurnal Bisnis Dan Ekonomi (JBE).

Bockholt, M. T., Hemdrup Kristensen, J., Colli, M., Meulengracht Jensen, P., \& Vejrum Wæhrens, B. (2020). Exploring factors affecting the financial performance of end-of-life take-back program in a discrete manufacturing context. Journal of Cleaner Production, 258, 120916. https://doi.org/https://doi.org/10.1016/j.jclepro.2020.120916

Bouzgarrou, H., Jouida, S., \& Louhichi, W. (2018). Bank profitability during and before the financial crisis: Domestic versus foreign banks. Research in International Business and Finance, 44, 26-39. https://doi.org/https://doi.org/10.1016/j.ribaf.2017.05.011

Brigham, E. F., \& Houston, J. F. (2011). Dasar-dasar manajemen Keuangan (Buku 2 - Edisi 11). In Salemba Empat.

Chen, M.-H. (2010). The economy, tourism growth and corporate performance in the Taiwanese hotel industry. Tourism Management, 31(5), 665-675. https://doi.org/https://doi.org/10.1016/j.tourman.2009.07.011

Hanum, Z. (2017). Akuntansi Perpajakan. Akuntansi Perpajakan.

Harahap, S. S. (2009). Analisa Kritis Laporan Keuangan. In Teori Akuntansi. https://doi.org/www.rajagrafindo.com

Hery. (2019). Akuntansi Dasar 1 dan 2. FUNDAMENTAL MANAGEMENT JOURNAL.

Hery, S. . (2015). Praktis Menyusun Laporan Keuangan. In Prekatis Menysun Laporan Keuangan Cepat \& Mahir Menyajikan.

Horne, J.C. dan Wachowicz, J. M. (2007). Prinsip-Prinsip Manajemen Keuangan. In PrinsipPrinsip Manajemen Keuangan. https://doi.org/10.4324/9781315641348

Ismail, A., Sulur, A. H., Akib, H., \& Salam, R. (2016). Snapshot of Society Social-Economic 
236|Jurnal Administrare: Jurnal Pemikiran Ilmiah dan Pendidikan Administrasi Perkantoran

Volume 6 Number 2 July- December 2019. Pages 229-236

Welfare based on Human Development Index in Polewali Mandar Regency, Indonesia. International Conference on Public Organization VI (ICONPO VI), 847-858. Thammsat University, Tha Prachan Campus.

Jamaluddin, J., Sari, W. I., Akib, H., Kasmita, M., \& Tadampali, A. C. T. (2019). The Influence of Spirit at Work on Employee Productivity at PT Millenium Penata Futures Makassar. Pinisi Business Administration Review, 1(1), 11-20.

Kasmir. (2014a). Bank dan Lembaga Kuangan Lainnya. In PT. Raja Grafindo Persada jakarta.

Kasmir. (2014b). Laporan Keuangan Bank. Manajemen Perbankan.

Munawir. (2010). Analisa Laporan Keuangan Edisi 4. In Jakarta: Salemba Empat.

Niswaty, R., AM, H. L., Saleh, S., Baharuddin, A., \& Arhas, S. H. (2019). The Implementation Effect of Industrial Work Practices on Student Work Readiness. Pinisi Business Administration Review, 1(1), 21-30.

Pessarossi, P., Thevenon, J.-L., \& Weill, L. (2020). Does high profitability improve stability for European banks? Research in International Business and Finance, 53, 101220. https://doi.org/https://doi.org/10.1016/j.ribaf.2020.101220

Rahma, A.M., Cipta, W., \& Yudiaatmaja, F. (2016). Pengaruh Likuiditas, Solvabilitas Dan Aktivitas Terhadap Profitabilitas Pada Perusahaan Otomotif Yang Terdaftar Di Bursa Efek Indonesia Periode 2012-2014. E-Journal Bisma Universitas Pendidikan Ganesha.

Samsir, A. (2017). Determinan Pertumbuhan Ekonomi Propinsi Sulawesi Selatan. Jurnal Office, $3(1), 51-55$.

Susianti, I. (2018). Analisis Laporan Keuangan Untuk Menilai Kinerja Keuangan Pada PT . Gudang Garam Tbk . Pada Periode 2013 - 2015. Simki-Economic.

Susilawati, C. D. K. (2012). Analisis Perbandingan Pengaruh Likuiditas, Solvabilitas, dan Profitabilitas Terhadap Harga Saham pada Perusahaan LQ 45. Jurnal Akuntansi.

Sutrisno. (2013). Manajemen Keuangan Teori Konsep dan Aplikasi. In Manajemen Keuangan Teori Konsep dan Aplikasi.

Tzouvanas, P., Kizys, R., Chatziantoniou, I., \& Sagitova, R. (2019). Environmental and financial performance in the European manufacturing sector: An analysis of extreme tail dependency. The British Accounting Review, 100863. https://doi.org/https://doi.org/10.1016/j.bar.2019.100863 